\title{
What Role Does Elevational Variation Play in Determining the Stock and Composition of Litter?
}

\author{
Humberto Araújo de Almeida, ${ }^{1,2}$ (D) 0000-0002-0390-377X \\ Maiara Bezerra Ramos² (D) 0000-0002-2932-2869 \\ Fabrício Correia Diniz ${ }^{2}$ (D) 0000-0001-6058-2936 \\ Sérgio de Faria Lopes² (D) 0000-0001-6472-6765
}

\begin{abstract}
This study analyzed the role of Caatinga vegetation structure in the accumulation, composition and distribution of litter along an elevation gradient in the Brazilian semi-arid region. Fifty sampling units were established for shrub-tree vegetation analysis, and $501-\mathrm{m}^{2}$ plots for sampling litter. Sampled litter was screened in fractions of leaves, stems, reproductive structures, miscellaneous and animal remains and then weighed. Total accumulated litter weighed $72.3 \mathrm{~kg}$ and was composed mainly of stems (45.2\%). A positive correlation was found between total litter and elevation, as well as between leaf fraction and richness and basal area, while the stem fraction was negatively associated with richness, abundance and basal area. The results reflect a joint effect of abiotic factors and community structure, which produces heterogeneous environments that favor variation in litter production and quality along the elevation gradient.
\end{abstract}

Keywords: elevation gradient, Caatinga, necromass, Serra da Arara.

\section{INTRODUCTION AND OBJECTIVES}

Litter represents one of the main components of forest ecosystems, being formed by a set of vegetal materials (leaves, branches, fruits, flowers and roots) and animal residues that accumulate on the soil (Salgado et al., 2015). This material decomposition is crucial to the continuity of biogeochemical cycles, the maintenance of soil fertility (Alonso et al., 2015; Ndagurwa et al., 2015; Vital et al., 2004) and, consequently, the absorption of nutrients by plants with a direct influence on the plant community (Butenschoen et al., 2014; Fisher et al., 2013).

Litter production and decomposition rate vary among different ecosystems. These processes are mainly controlled by climate and necromass quality but are also influenced by edaphic factors and the decomposer biota (García-Palacios et al., 2015). Climate acts indirectly on vegetal material decomposition which, along with successional stage of the vegetation and litter quality, is essential to establish the decomposer community, either by the constitution of plant materials or by the constitution of microhabitats favorable for its development (Anaya et al., 2012; Brandt et al., 2010; Diedhiou et al., 2009; Wardle et al., 2004). Litter quality is essential for decomposition (Uselman et al., 2011; Veen et al., 2015), because the composition of different plant organs, whether from the same or different species, is a preponderant factor for the speed by which litter is decomposed (Lorenzo et al., 2013), and nutrients returned to the soil (Li et al., 2011).

In semi-arid ecosystems with low water availability, the greatest deposition of plant remains occurs during the drought period shortly after the fall of foliage, increasing the accumulated litter that will decompose when rainy season begins (Alves et al., 2006; Santana \& Souto, 2011). Greater necromass accumulation in these ecosystems is also directly related to high temperatures, which, alongside low rainfall, intensifies soil dryness. This, in turn, reduces the period of adequate humidity for decomposition, which directly influences the microbial community whose activities occur only in favorable humidity and temperature conditions, usually during the rainy season (Couteaux, 1995; Davies et al., 2013; Schuster et al., 2005). Thus, in semi-arid ecosystems, photodegradation represents the main decomposing agent during the dry season (Austin \& Vivanco, 2006).

\footnotetext{
${ }^{1}$ Universidade Federal de Minas Gerais (UFMG), Belo Horizonte, MG, Brasil

${ }^{2}$ Universidade Estadual da Paraíba (UEPB), Campina Grande, PB, Brasil
} 
Mountainous areas are considered true refuges for biodiversity in the Brazilian semi-arid (Oliveira et al., 2009; Silva et al., 2014), being areas of relatively preserved native vegetation (Caatinga) with great richness and endemism of plant species (Lopes et al., 2017; Silva et al., 2014). Several environmental factors, including solar radiation, wind speed and humidity, together with topographic variables, change along elevation gradients, such as mountainous (Rezende et al., 2015). These changes directly affect vegetation composition and structure, which in turn influences the habitat and litter quality (Cornelissen et al., 2012), thus promoting variation in accumulation and decomposition of plant residues (Godinho et al., 2014).

Therefore, to understand the main determinants of litter accumulation in semi-arid mountainous areas, we analyzed how vegetation structure relates to the contribution to, and composition of, litter accumulated on the soil surface in a semi-arid mountain range in Brazil. The aim was to address two questions: does elevation play an important role in the contribution of litter to mountains in semi-arid environments? If so, how does variation in elevation affect the contribution to, and composition of, litter?

\section{MATERIALS AND METHODS}

\subsection{Study area}

The present study took place in Serra da Arara, municipality of São João do Cariri $\left(07^{\circ} 23^{\prime} 27^{\prime \prime}\right.$ S, $\left.36^{\circ} 31^{\prime} 58^{\prime \prime} \mathrm{W}\right)$, located in the Cariri Ocidental microregion in the Borborema mesoregion of the state of Paraíba, Brazil (Figure 1). The elevation of Serra da Arara ranges from 400 to 650 meters above sea level, and despite its narrow elevation range, the elevation gradients exhibit differences in plant community composition, structure, richness and diversity (Lopes et al., 2017; Silva et al., 2014). The predominant vegetation in the mountain range is characterized by arboreal shrub Caatinga, which is adapted to conditions of water deficit and composed of low trees and shrubs with spines, microphylls and other xerophytic characteristics (Prado, 2008).

Following the Köeppen-Geiger classification, the climate of the region is type Bswh, hot semi-arid (Francisco et al., 2016), with two defined seasons, the dry season and the rainy season (between March and July), with a mean annual rainfall of $300 \mathrm{~mm}$. The predominant soils of the region are Vertisol and eutrophic Litolic (EMBRAPA, 2013).

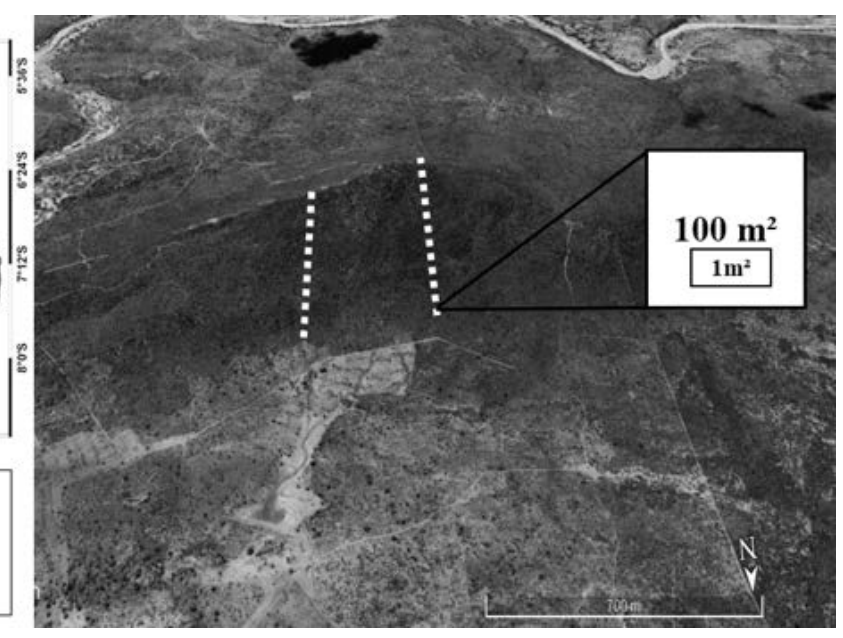

Figure 1. Map of Serra da Arara, municipality of São João of Cariri, indicating its location in the state of Paraíba, Brazil and the sample design for data collection.

\subsection{Data collection}

Data on species composition and plant community structure were collected by Diniz (2016), who established two transects along the elevation gradient (from the base to the top of the mountain range) (Figure 1). Twenty-five $100-\mathrm{m}^{2}$ plots $(10 \times 10 \mathrm{~m})$ were established along each transect for a total of 50 plots. All individual living plants with height $\geq 1 \mathrm{~m}$ and stem diameter at soil level (DAS) $\geq 3 \mathrm{~cm}$ in each plot were sampled, identified and marked. DAS measurement was made using a caliper and metric tape with direct reading for diameter and perimeter. For individuals with multiple stems (several shafts), the diameter of each stem was measured and the total diameter of the individual calculated. Plant height was measured by a 12 -meter graduated collecting pruner. A total of 1654 individuals of 34 species belonging to 13 families were sampled for a total basal area of $16.71 \mathrm{~m}^{2} /$ ha (Diniz, 2016). 
Litter collection was done at the end of the dry season of 2014. Necromass was gathered using a $1 \mathrm{~m} \times 1 \mathrm{~m}(1 \mathrm{~m} 2)$ cast frame made of PVC pipes placed randomly on the soil of each plot. Thus, a litter sample was collected from each of the $100 \mathrm{~m}^{2}$ plots that had been established for the collection of vegetation data. All the material present was compiled and taken to the Laboratory of Ecology \& Conservation of Dry Tropical Forest (EcoTropics) of the Universidade Estadual da Paraíba for screening, then separated into the following fractions: leaves (including leaflets and petioles), stems (including bark and other woody parts), reproductive structures (flowers, fruits and seeds), miscellaneous (unidentified material) and animal residues (Lopes et al., 2015). After separation, the material was dried in an air circulation oven at $65^{\circ} \mathrm{C}$ for 24 hours and weighed on a precision scale to obtain the weight of samples in grams.

Slope, rockiness and elevation were measured in each plot. Slope of the terrain was measured with a clinometer at three sites within each plot. Rocky cover (rocky outcrop or rockiness) was estimated by classifying the cover percentage into one of four categories: Class 1, 0 to $25 \%$ of outcrop; Class 2, 26 to 50\%; Class 3, 51 to $75 \%$; and Class 4, 76 to $100 \%$ (Abreu et al., 2012).

\subsection{Data analysis}

The structural parameters - abundance, basal area and richness - of the community were calculated by the FITOPAC Shell version 2.1 program (Shepherd, 2010). The influence of elevation and community structural variables on litter fractions was first evaluated by constructing a correlogram, following the exploratory displays method for Spearman correlation matrices, to detect the most significant relationships. All possible combinations of elevation, structural variables (abundance, basal area and rarefied richness) and total litter and its fractions, were used in the graphic matrix. This study used species rarefied richness rather than species richness to correct for the positive noise of the effect of tree density on richness. Rarefied wealth was calculated using the EcoSim software version 7.71. Rarefaction is used to correct for the effect of density variation of individuals in a given area by performing 1,000 permutations by randomly drawing a specific number of individuals to generate an average variation of species diversity. To calculate rarefied richness, we used a random sample of 12 individuals since this was the minimum number found in most plots. Linear regressions were subsequently performed, and an analysis of residuals and outliers removal were also carried out. Scatter plots were ultimately constructed to better visualize the results. The analyses were performed using the PAST 2.17c program (Hammer et al., 2001).

\section{RESULTS}

The necromass accumulated on the soil surface of the 50 plots totaled $72.3 \mathrm{~kg}$, for an estimated of $14,470 \mathrm{~kg} / \mathrm{ha}$ (Table 1). Stem fraction was the most representative, being responsible for $45.2 \%(32.74 \mathrm{~kg})$ of the total accumulated litter. The miscellaneous fraction was next, followed by leaf fraction, which corresponded to $18.9 \%$ of the total litter weight (Table 1).

Table 1. Mean and standard deviation $(n=50)$ of litter fractions per sample in Serra da Arara, Paraíba, Brazil.

\begin{tabular}{|lcccc|}
$\begin{array}{l}\text { Composition } \\
\text { of litter }\end{array}$ & $\begin{array}{c}\text { Average } \\
\left(\mathrm{Kg} / \mathbf{m}^{2}\right)\end{array}$ & $\begin{array}{c}\text { Standard } \\
\text { deviation }\end{array}$ & $\begin{array}{c}\text { Total } \\
\text { accumulated } \\
(\mathbf{k g})\end{array}$ & $\%$ \\
\hline Woody debris & 0.654 & 0.501 & 32.7 & 45.2 \\
\hline Miscellaneous & 0.326 & 0.269 & 16.3 & 22.5 \\
\hline Leaf & 0.274 & 0.191 & 13.7 & 18.9 \\
\hline $\begin{array}{l}\text { Animal } \\
\text { residues }\end{array}$ & 0.085 & 0.107 & 4.2 & 5.8 \\
\hline $\begin{array}{l}\text { Reproductive } \\
\text { materials }\end{array}$ & 0.027 & 0.115 & 1.3 & 1.8 \\
\hline Total litter & 1.447 & 0.698 & 72.35 & 100 \\
\hline
\end{tabular}

The litter deposited on the soil was distributed along the mountain range in a manner that positively correlated with elevation $\left(\mathrm{rs}=0.35 ; \mathrm{r}^{2}=0.12 ; \mathrm{F}=6.54 ; \mathrm{df}=1.46 ; p=0.014\right.$ ) (Figure 2a). Thus, regions at higher elevations had a greater litter volume, which corresponds to the trend for greater vegetation species richness at higher elevations $\left(\mathrm{rs}=0.36 ; \mathrm{r}^{2}=0.13 ; \mathrm{F}=4.92\right.$; $\mathrm{df}=1.43 ; p=0.013$ ) (Figure 2b). Moreover, this area of the mountain range is also associated with greater slope $(\mathrm{rs}=0.60$; $p<0.001$ ) (Figure 3a) and rockiness ( $r s=0.53 ; p<0.001$ ).
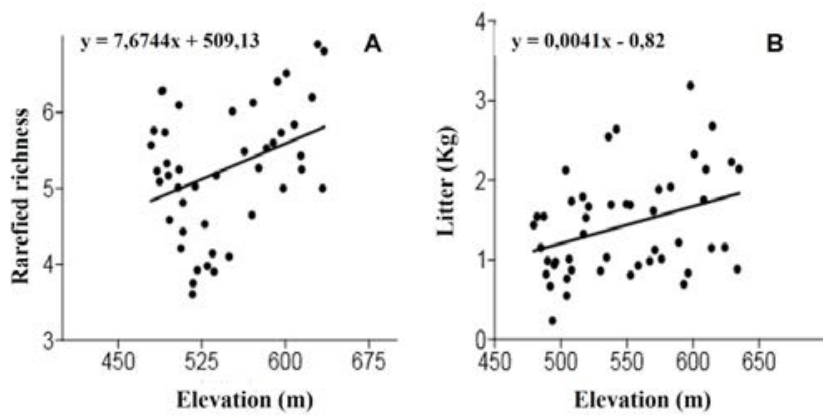

Figure 2. Linear regression between total litter and elevation (a), and rarefied richness and elevation (b).

No significant correlations were found between total accumulated litter and any vegetation parameter $(p>0.05)$. However, when analyzing the litter fractions, the accumulation of leaf fraction was found to positively correlated with rarefied 
richness ( $\mathrm{rs}=0.39 ; p=0.007)$ (Figure $3 \mathrm{~b}$ ) and total basal area ( $\mathrm{rs}=0.28 ; p=0.03$ ) (Figure 3c). In contrast, production and/ or decomposition of woody debris (stem) was negatively correlated with rarefied richness ( $\mathrm{rs}=-0.32 ; p=0.02$ )
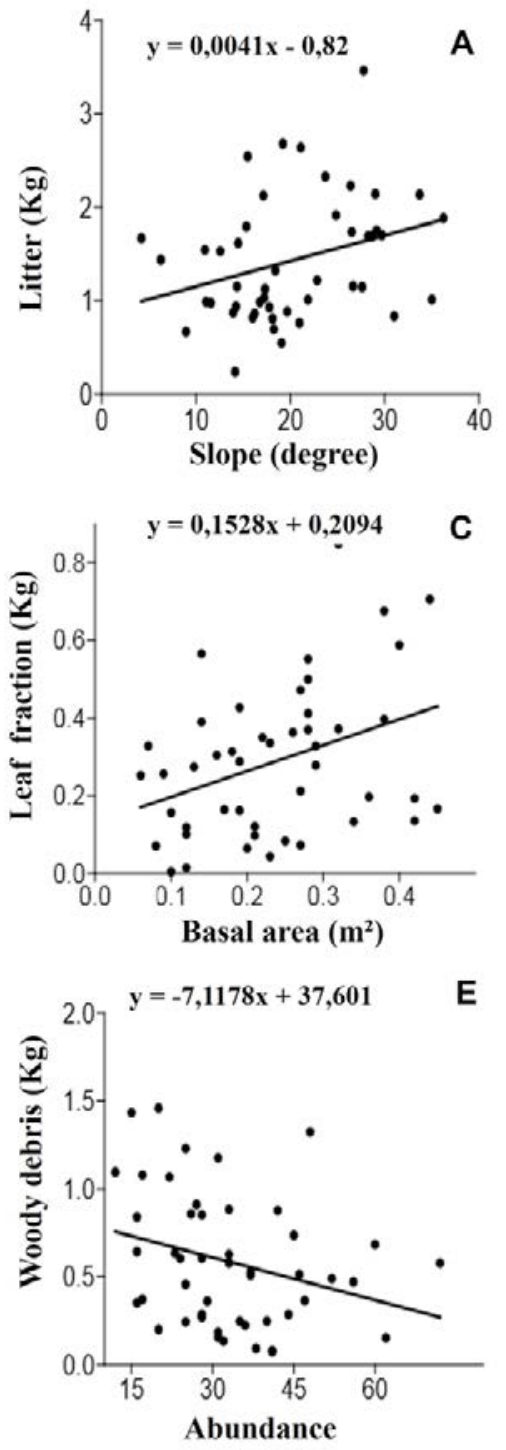

(Figure $3 \mathrm{~d}$ ), abundance $(\mathrm{rs}=-0.28 ; p=0.04)$ (Figure $3 \mathrm{e})$, and basal area ( $\mathrm{rs}=-0.33 ; p=0.02$ ) (Figure $3 \mathrm{f}$ ), in such a way that an increase in these vegetation parameters meant a decrease in the presence (deposition) of this plant organ on the soil.
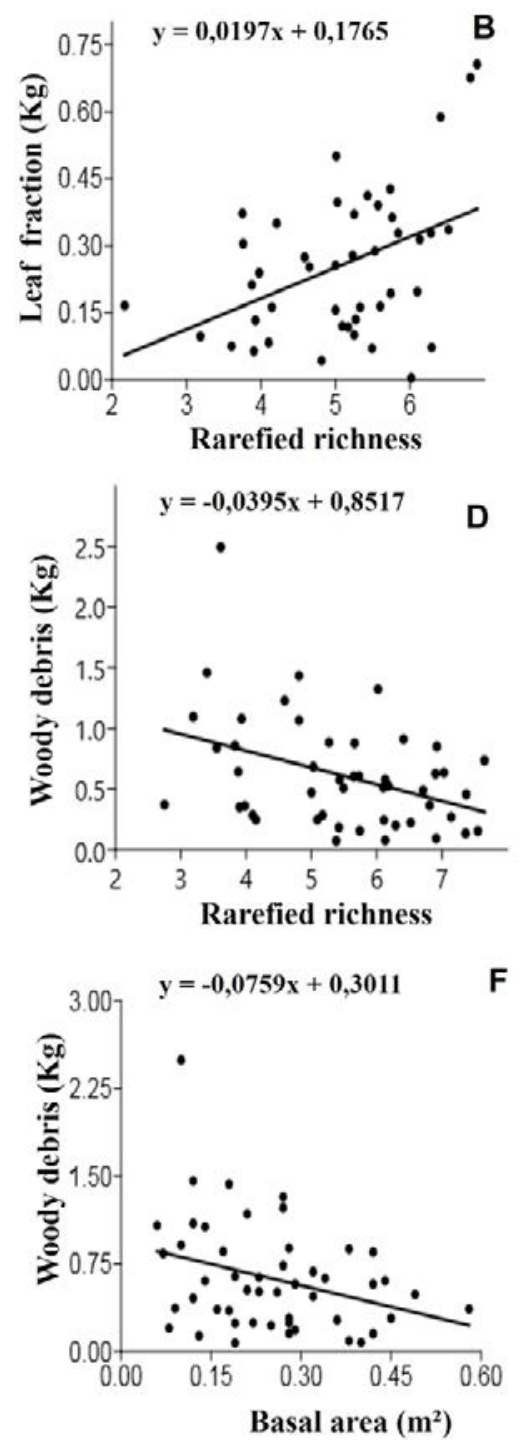

Figure 3. Linear regression between total litter and slope (a); leaf $\times$ estimated richness (b); leaf $\times$ basal area $(\mathrm{c})$; stem $\times$ estimated richness $(\mathrm{d})$; stem $\times$ abundance $(\mathrm{e})$; stem $\times$ basal area $(\mathrm{f})$.

No significant $(p>0.05)$ correlations were found between any environmental or biological variable and other litter fractions (reproductive materials, animal residues). However, when analyzing the composition of animal residues, a predominance of feces and bones of grazing animals in the area surrounding the mountain (goats and donkey) was found in the most basal portions of the mountain range.

\section{DISCUSSION}

A high volume of accumulated litter $(14,470 \mathrm{~kg} / \mathrm{ha})$ was found in the study area of this research, which is higher than that found by Lima et al. (2010), who reported $8,400 \mathrm{~kg} /$ ha for a Caatinga area in the state of Piauí. Furthermore, although low litter production is usual for the Caatinga, when 
compared to other vegetation formations (Lopes et al., 2010), the studied mountainous region had greater accumulated litter on the soil surface than that reported by the Atlantic Semideciduous Forests, for which values between 6.1 and 9.4 thousand $\mathrm{kg} / \mathrm{ha}$ have been reported (Borém \& Ramos, 2002; Caldeira et al., 2013). The litter accumulation found in the present study is also higher than the $10,291.20 \mathrm{~kg} / \mathrm{ha}$ reported for a remnant of cerrado stricto sensu (Lima RP et al., 2015). The contribution evidenced in the present study comprises the results of years of accumulation; the analyzed necromass had likely been deposited gradually over the years and its decomposition has occurred slowly, denoted by the greater abundance of slow decomposition organs (stem), which require a longer period to decompose.

The high volume of litter observed in this study may also comprehend the collection period since, as evidenced by other studies in Caatinga areas, the greatest deposition of vegetal debris occurs during the dry season (Salgado et al., 2015; Santana \& Souto, 2011; Santos et al., 2011), a period of low rate of decomposition because of the slow action of decomposer microorganisms, for their sensitivity to high temperatures and low humidity (Couteaux et al., 1995; Holanda et al., 2015). Thus, the material is decomposed only in the subsequent rainy season when favorable conditions for the development of decomposer biota are reestablished (Davies et al., 2013).

This high contribution of necromass can also be attributed to the greater richness and species diversity found in semi-arid regions (Lopes et al., 2017; Silva et al., 2014). To Godinho et al. (2014), litter production is directly associated with species richness. This parameter directly influences necromass quality and is thus considered a preponderant factor in decomposition (García-Palacios et al., 2015).

The analyzed mountain range shows spatial variability in the production and/or decomposition of litter, what may correspond to the structural characteristics of the vegetation, which, as shown here, are reflected in the quality and productivity of leaf and stem organs. This variation in litter quality may directly correlate with the characteristics of the mountain ecosystem itself, since higher elevation areas have decreased availability of nutrients in the soil because of leaching (Rodrigues et al., 2016), making plants in higher elevation and slope regions develop organs with a low concentration of nutrients and high content of phenolic compounds, which attenuate the necromass decomposition rate (Werner \& Homeier, 2015).

Besides the influence of litter quality (Holanda et al., 2015), higher accumulation at higher elevations may arise from the reduced rates of decomposition in this mountain range area. Greater slope and rockiness play such an essential role in the decomposition of plant remains (Ndagurwa et al., 2015) that greater rock cover may negatively interfere in the contact between necromass and the invertebrates that act in vegetal material decomposition, thereby delaying the cycling process and promoting greater accumulation (Davies et al., 2013).

The stem fraction of the litter was the most representative ( $45.2 \%$ of all collected material), differing from that found by studies of dynamics carried out in Caatinga areas, which found a higher percentage of leaves (Lima NL et al., 2015; Lopes et al., 2015; Santana \& Souto, 2011). In contrast to the present study, studies of dynamics analyze monthly productivity, disregarding the effects of decomposition in litter deposited on the ground. Thus, regarding accumulated necromass, which is subjected to the effects of decomposing agents, a greater presence of organs with a high predominance of recalcitrant compounds, such as lignin, waxes and phenolic compounds, which have low decomposition rates, is presumed (Freschet et al., 2012; Laiho \& Prescott, 2004).

The low speed of wood decomposition, when compared to other vegetal debris, is mainly a result of the microstructure of the cell wall of the wood tissue; the higher lignin, polyphenols, cellulose, and dry matter (Cornelissen et al., 2012; Freschet et al., 2012) content, are responsible for making the stem more recalcitrant to decomposition. As a result of the slow decomposition rate and low nutrient content, mainly $\mathrm{N}$ and $\mathrm{P}$, wood decomposition slowly returns nutrients to the soil (Laiho \& Prescott, 2004; Laughlin et al., 2015). However, wood residues are of extreme importance, especially in semi-arid regions, since the layer formed by this debris retains moisture and promotes environmental conditions and suitable habitats for the decomposer biota, as well as retaining organic matter in the soil, favoring nutrient cycling and the decomposition of other vegetal debris (Laiho \& Prescott, 2004).

Although productivity studies in Caatinga regions indicate leaf fraction as the most representative in litter (Lopes et al., 2010; Lopes et al., 2015; Santana \& Souto, 2011), the lower percentage of leaves found in the present study may arise from the higher decomposition rate of this organ, which is spread abundantly and homogeneously on the soil surface contributing more quickly to the return of nutrients (Laughlin et al., 2015).

On the other hand, greater leaf production and/or accumulation were positively correlated with species richness and basal area, increasing data from previous studies in Caatinga areas where only a relationship between litter productivity and abundance of individuals was found (Lopes et al., 2015). Regions with greater species richness have higher necromass production on the ground because of niche complementarity, a network composed of different species endowed with complementary functional characteristics, which allow for a better establishment and development of 
vegetal biota (Poorter et al., 2015). Furthermore, an increase in richness directly interferes with soil respiration and reduction of available nutrients in the substrate, especially nitrogen, thus reducing the decomposition rate (Cardinale et al., 2012). Therefore, the close relationship between the greater contribution of leaves and greater species richness is possibly a result of high leaf yield and low decomposition rate in areas of high plant richness.

Despite the absence of any correlations between animal residues and elevation, a higher concentration was observed at the foot of the mountain range, where the fraction is basically composed of feces and bones from goats and donkey grazing in the surroundings of the mountain range. These animals have been reported as a strong threat to the richness and diversity of Caatinga plants because of their intense foraging on native species (Alves et al., 2009; Santos et al., 2012). Grazing breeds in the regions surrounding Caatinga mountains may be a threat to the ecosystem heritage that has been recognized as a refuge for biodiversity (Lopes et al., 2017; Silva et al., 2014), and cause the loss of the few remnants of conserved Caatinga.

\section{CONCLUSIONS}

As elevation increases in mountainous environments, an increase in the accumulation of necromass on the ground is found. The different environmental conditions present in Brazilian semi-arid ecosystems create various microhabitats, which have higher litter productivity as a result of vegetative attributes variation that favors range in necromass quality. This variation in quality, in turn, reflects different decomposition rates and, consequently, different litter accumulation rates. Regions at higher elevations possess greater species richness and basal area, thus, a higher concentration of leaves. The high proportion of stem in the accumulated litter (organs with a high content of recalcitrant compounds) results from reduced decomposition rates semi-arid environments, which usually require longer periods to reach complete decomposition; leaves, which decompose faster, represented a lesser proportion of the total accumulated litter.

\section{ACKNOWLEDGEMENTS}

The authors thank the Universidade Estadual da Paraíba for logistical support for access to the study areas. Sonaly Cunha da Silva, Pablo José da Silva and D’Ávilla Ruama Fernandes Lopes Gomes for their help with field activities, and the Laboratory of Plant Ecology of the Universidade Estadual da Paraíba. We thank also the reviewers for the valuable suggestions and the Conselho Nacional de Desenvolvimento Científico e Tecnológico (CNPq) for the financial support and the productivity grant awarded to SFL.

\section{SUBMISSION STATUS}

Received: 16 Apr. 2018

Accepted: 24 Nov. 2018

Associate editor: Marcos Gervásio Pereira

(iD) 0000-0002-1402-3612

\section{CORRESPONDENCE TO}

\section{Humberto Araújo de Almeida}

Universidade Estadual da Paraíba (UEPB), Rua Baraúnas, 351, Universitário, CEP 58429-500, Campina Grande, PB, Brasil

e-mail: humbertoalmeida4@gmail.com

\section{FINANCIAL SUPPORT}

Conselho Nacional de Desenvolvimento Científico e Tecnológico (CNPq).

\section{REFERENCES}

Abreu MF, Pinto JRR, Maracahipes L, Gomes L, Oliveira EA, Marimon BS et al. Influence of edaphic variables on the floristic composition and structure of the tree-shrub vegetation in typical and rocky outcrop cerrado areas in Serra Negra, Goiás State, Brazil. Brasilian Journal of Botany 2012; 35(3): 259-272.

Alonso m, Leles PSS, Ferreira LN, Oliveira NSA. Aporte de serapilheira em plantio de recomposição florestal em diferentes espaçamentos. Ciência Florestal 2015; 25(1): 1-11. 10.5902/1980509817439

Alves AR, Souto JS, Souto PC, Holanda AC. Aporte e decomposição de serrapilheira em área de Caatinga, na Paraíba. Revista de Biologia e Ciências da Terra 2006; 6(2): 194-203.

Alves JJA, Araújo MA, Nascimento SS. Degradação da Caatinga: uma investigação ecogeográfica. Revista Caatinga 2009; 22(3): 126-135.

Anaya CA, Jaramillo VJ, Martínez-Yrízar A, García-Oliva F. Large rainfall pulses control litter decomposition in a tropical dry forest: evidence from an 8-year study. Ecosystems 2012; 15(4): 652-663. $10.1007 / \mathrm{s} 10021-012-9537-\mathrm{Z}$

Austin AT, Vivanco L. Plant litter decomposition in a semi-arid ecosystem controlled by photodegradation. Nature 2006; 442 (7102): 555-558. 10.1038/nature05038

Borém RAT, Ramos DP. Variação estacional e topográfica de nutrientes na serapilheira de um fragmento de mata atlântica. Cerne 2002; 8(2): 42-59.

Brandt LA, King JY, Hobbie SE, Milchunas DG, Sinsabaugh RL. The role of photodegradation in surface litter decomposition across a grassland ecosystem precipitation gradient. Ecosystems 2010; 13(5): 765-781. 10.1007/s10021-010-9353-2

Butenschoen O, Krashevska V, Maraun M, Marian F, Sandmann $\mathrm{D}$, Scheu S. Litter mixture effects on decomposition in tropical montane rainforests vary strongly with time and turn negative at later stages of decay. Soil Biology and Biochemistry 2014; 77: 121128. 10.1016/j.soilbio.2014.06.019

Caldeira MVW, Silva RD, Kunz SH, Zorzanelli JPF, Castro KC, Godinho TO. Biomassa e nutrientes da serapilheira em diferentes coberturas florestais. Comunicata Scientiae 2013; 4(2): 111-119. 
Cardinale BJ, Duffy JE, Gonzalez A, Hooper DU, Perrings C, Venail $P$ et al. Biodiversity loss and its impact on humanity. Nature 2012; 486(7401): 59-67. 10.1038/nature11148

Cornelissen JHC, Sass-Klaassen U, Poorter L, Geffen KV, Logtestijn RSPV, Hal JV et al. Controls on coarse wood decay in temperate tree species: birth of the LOGLIFE experiment. Ambio 2012; 41(3): 231-245. 10.1007/s13280-012-0304-3

Couteaux MM, Bottner P, Berg B. Litter decomposition, climate and liter quality. Trends in Ecology and Evolution 1995; 10(2): 63-66. 10.1016/S0169-5347(00)88978-8

Davies AB, Van-Rensburg BJ, Eggleton P, Parr CL. Interactive effects of fire, rainfall, and litter quality on decomposition in savannas: frequent fire leads to contrasting effects. Ecosystems 2013; 16(5): 866-880. 10.1007/s10021-013-9657-0

Diedhiou S, Dossa EL, Badiane AN, Diedhiou I, Sene M, Dick RP. Decomposition and spatial microbial heterogeneity associated with native shrubs in soils of agroecosystems in semi-arid Senegal. Pedobiologia 2009; 52(4): 273-286. 10.1016/j.pedobi.2008.11.002

Diniz FC. Composição e estrutura de comunidades arbustivo/arbóreas ao longo de um gradiente altitudinal no semiárido brasileiro [thesis]. Campina Grande: Universidade Estadual da Paraíba; 2016.

Empresa Brasileira de Pesquisa Agropecuária - EMBRAPA. Sistema brasileiro de classificação de solos. 3rd ed. Brasília, DF: EMBRAPA; 2013.

Fisher JP, Phoenix GK, Childs DZ, Press MC, Smith SW, Pilkington MG, Cameron DD. Parasitic plant litter input: a novel indirect mechanism influencing plant community structure. New Phytologist 2013; 198(1): 222-231. 10.1111/nph.12144

Francisco PRM, Medeiros RM, Santos D, Matos RM. Classificação climática de Köppen e Thornthwaite para o estado da Paraíba. Revista Brasileira de Geografia Física 2016; 8(4): 1006-1016. 10.26848/rbgf. v8.4.p1006-1016

Freschet GT, Aerts R, Cornelissen JH. Multiple mechanisms for trait effects on litter decomposition: moving beyond home-field advantage with a new hypothesis. Journal of Ecology 2012; 100(30): 619-630. 10.1111/j.1365-2745.2011.01943.x

Freschet GT, Cornwell WK, Wardle DA, Elumeeva TG, Liu W, Jackson BG et al. Linking litter decomposition of above-and belowground organs to plant-soil feedbacks worldwide. Journal of Ecology 2013; 101(4): 943-952. 10.1111/1365-2745.12092

García-Palacios P, McKie BG, Handa IT, Frainer A, Hättenschwiler $S$. The importance of litter traits and decomposers for litter decomposition: a comparison of aquatic and terrestrial ecosystems within and across biomes. Functional Ecology 2015; 30(5): 819-829. $10.1111 / 1365-2435.12589$

Godinho TO, Caldeira MVW, Rocha JHT, Caliman JP, Trazzi PA. Quantificação de biomassa e nutrientes na serapilheira acumulada em trecho de floresta estacional semidecidual submontana, ES. Cerne 2014; 20(1): 11-20. 10.1590/S0104-77602014000100002

Hammer O, Harper DAT, Ryan PD. PAST: paleontological statistics software package for education and data analysis. Palaeontolia Electronica 2001; 4(1): 9.

Holanda AC, Feliciano ALP, Marangon LC, Freire FJ, Holanda EM. Decomposição da serapilheira foliar e respiração edáfica em um remanescente de Caatinga na Paraíba. Revista Árvore 2015; 39(2): 245-254. 10.1590/0100-67622015000200004

Laiho R, Prescott CE. Decay and nutrient dynamics of coarse woody debris in northern coniferous forests: a synthesis. Canadian Journal of Forest Research 2004; 34(4): 763-777. 10.1139/x03-241

Laughlin DC, Richardson SJ, Wright EF, Bellingham PJ. Environmental filtering and positive plant litter feedback simultaneously explain correlations between leaf traits and soil fertility. Ecosystems 2015; 18(7): 1269-1280. 10.1007/s10021-015-9899-0

Li LJ, Zeng DH, Yu ZY, Fan ZP, Yang D, Liu YX. Impact of litter quality and soil nutrient availability on leaf decomposition rate in a semi-arid grassland of Northeast China. Journal of Arid Environments 2011; 75(9): 787-792. 10.1016/j.jaridenv.2011.04.009

Lima NL, Neto S, Melo C, Calil FN, Souza KRD, Moraes DCD. Acúmulo de serapilheira em quatro tipos de vegetação no estado de Goiás. Enciclopédia Biosfera 2015; 11(22): 39-46. 10.18677/ Enciclopedia_Biosfera_2015_068

Lima RP, Fernandes MM, Fernandes MRM, Matricardi EAT. Aporte e decomposição da serapilheira na Caatinga no sul do Piauí. Floresta e Ambiente 2015; 22(1): 42-49. 10.1590/2179-8087.062013

Lima SS, Leite LFC, Aquino AM, Oliveira FC, Castro AAJF. Serapilheira e teores de nutrientes em argissolo sob diferentes manejos no norte do Piauí. Revista Árvore 2010; 34(1): 75-84. 10.1590/S0100-67622010000100009

Lopes JFB, Andrade EM, Lobato FAO, Queiroz-Palácio HA, Arraes FDD. Deposição e decomposição de serapilheira em área da Caatinga. Revista Agroambiente 2010; 3(2): 72-79. 10.18227/1982-8470ragro. v3i2.252

Lopes MCA, Araújo VFP, Vasconcellos A. The effects of rainfall and vegetation on litterfall production in the semiarid region of northeastern Brazil. Brazilian Journal of Biology 2015; 75(3): 703708. 10.1590/1519-6984.21613

Lopes SF, Ramos MB, Almeida GR. The role of mountains as refugia for biodiversity in Brazilian Caatinga: conservationist implications. Tropical Conservation Science 2017; 10: 1-12. 10.1177/1940082917702651

Lorenzo L, Pérez-Harguindeguy N, Casanoves F, Oliveira AA. Recovering from forest-to-pasture conversion: leaf decomposition in central Amazonia, Brazil. Journal of Tropical Ecology 2013; 30(1): 93-96. 10.1017/S0266467413000771

Ndagurwa HGT, Dube JS, Mlambo D. Decomposition and nutrient release patterns of mistletoe litters in a semi-arid savanna, southwest Zimbabwe. Austral Ecology 2015; 40(2): 178-185. 10.1111/aec.12191

Oliveira PTB, Trovão DMBM, Carvalho ECD, Souza BC, Ferreira LMR. Florística e fitossociologia de quatro remanescentes vegetacionais em áreas de Serra no Cariri paraibano. Revista Caatinga 2009; 22(4): 169-178.

Prado DE. As Caatingas da América do Sul. In: Leal IR, Tabarelli M, Silva JMC. Ecologia e conservação da Caatinga. Recife: Editora Universitária da UFPE; 2008. p. 3-74.

Poorter L, Sande MT, Thompson J, Arets EJMM, Alarcón A, ÁlvarezSánchez et al. Diversity enhances carbon storage in tropical forests. Global Ecology and Biogeography 2015; 24(11): 1314-1328. 10.1111/ geb.12364 
Rezende VL, Miranda PLS, Meyer L, Moreira CV, Linhares MFM, Oliveira-Filho AT, Eisenlohr PV. Tree species composition and richness along altitudinal gradients as a tool for conservation decisions: the case of Atlantic semideciduous forest. Biodiversity and Conservation 2015; 24(9): 2149-2163. 10.1007/s10531-015-0939-Z

Ribeiro E, Santos BA, Arroyo-Rodríguez V, Tabarelli M, Souza G, Leal IR. Phylogenetic impoverishment of plant communities following chronic human disturbances in the Brazilian Caatinga. Ecology 2016; 97(6): 1583-1592. 10.1890/15-1122.1

Rodrigues PMS, Schaefer CEGR, Silva JO, Ferreira WG Jr, Santos RM, Neri AV. The influence of soil on vegetation structure and plant diversity in different tropical savannic and forest habitats. Journal of Plant Ecology 2016; 11(2): 226-236. 10.1093/jpe/rtw135

Salgado EV, Hevia JN, Nunes EP, Rodrigues MMDA. Rainfall patterns and the contribution of litter in the Caatinga dry tropical forest. Revista Ciência Agronômica 2015; 46(2): 299-309. 10.5935/1806-6690.20150009

Santana JAS, Souto JS. Produção de serapilheira na Caatinga da região semi-árida do Rio Grande do Norte, Brasil. Idesia 2011; 29(2): 87-94. 10.4067/S0718-34292011000200011

Santos PS, Souza JT, Santos JMFF, Santos DM, Araújo EL. Diferenças sazonais no aporte de serrapilheira em uma área de Caatinga em Pernambuco. Revista Caatinga 2011; 24(4): 94-101.

Santos RM, Oliveira-Filho AT, Eisenlohr PV, Queiroz LP, Cardoso DB, Rodal MJ. Identity and relationships of the arboreal Caatinga among other floristic units of seasonally dry tropical forests (SDTFs) of North-Eastern and Central Brazil. Ecology and Evolution 2012; 2(2): 409-428. 10.1002/ece3.91
Schuster TD, Cobb NS, Whitham TG, Hart SC. Relative importance of environmental stress and herbivory in reducing litter fall in a semiarid woodland. Ecosystems 2005; 8(1): 62-72. 10.1007/s10021-004-0001-6

Shepherd GJ. FITOPAC. Version 2.1. Campinas: Unicamp; 2010.

Silva FKG, Lopes SF, Lopez LCS, Melo JIM, Trovão DMBM. Patterns of species richness and conservation in the Caatinga along elevational gradients in a semiarid ecosystem. Journal of Arid Environments 2014; 110: 47-52. 10.1016/j.jaridenv.2014.05.011

Uselman SM, Snyder KA, Blank RR, Jones TJ. UVB exposure does not accelerate rates of litter decomposition in a semi-arid riparian ecosystem. Soil Biology and Biochemistry 2011; 43(6): 1254-1265. 10.1016/j.soilbio.2011.02.016

Veen GF, Freschet GT, Ordonez A, Wardle DA. Litter quality and environmental controls of home-field advantage effects on litter decomposition. Oikos 2015; 124(2): 187-195. 10.1111/oik.01374

Vital ART, Guerrini IA, Franken WK, Fonseca RCB. Produção de serapilheira e ciclagem de nutrientes de uma floresta estacional semidecidual em zona ripária. Revista Árvore 2004; 8(6): 793-800. 10.1590/S0100-67622004000600004

Wardle DA, Bardgett RD, Klironomos JN, Setälä H, Van Der Putten WH, Wall DH. Ecological linkages between aboveground and belowground biota. Science 2004; 304(5677): 1629-1633. 10.1126/ science. 1094875

Werner FA, Homeier J. Is tropical montane forest heterogeneity promoted by a resource-driven feedback cycle? Evidence from nutrient relations, herbivory and litter decomposition along a topographical gradient. Functional Ecology 2015; 29(3): 430-440. $10.1111 / 1365-2435.12351$ 